Animal Health Research Institute,

Assiut, Egypt.

\title{
BIOCHEMICAL AND PATHOLOGICAL STUDIES OF COBALT LEVEL IN SLAUGHTERED CATTLE AND BUFFALOES IN ASSIUT GOVERNORATE
}

(With 3 Tables and 7 Figures)

\author{
By
}

\section{EMAN M.A. EL-NASER; NEVEN A.EL. NISR and \\ EMAN EZZ EL-DAWLA ELSHARKWAY*}

* Dept. of Forensic Medicine, Faculty of Veterinary Medicine, Assiut University, Assiut Egypt.

(Received at 1/11/2011)

$$
\text { دراسات بيوكيميائية وباثولوجية عن مستوي الكوبالت في الأبقار والجاموس أسبوط }
$$

إيمان محد عب//ناصر ، نيفين عبل الغتي النسر ، إيمان عز الدولة الثرقاوى

أجريت هذه الدر اسة للتعرف على القيم المختلفة لمستوى الكوبلت في الأبقار و الجاموس قيد فيد

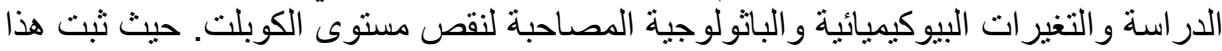

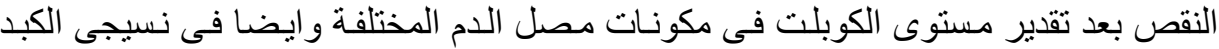

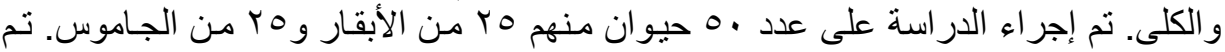

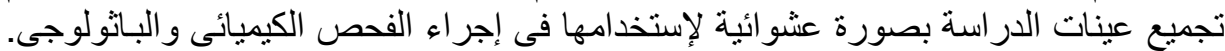

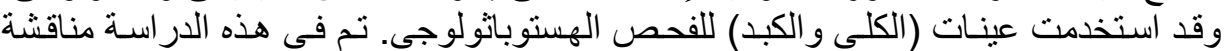

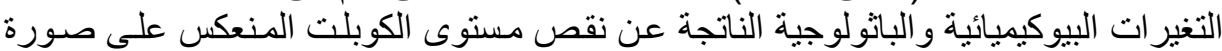

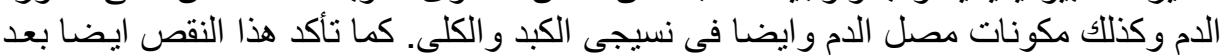

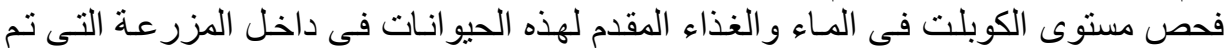

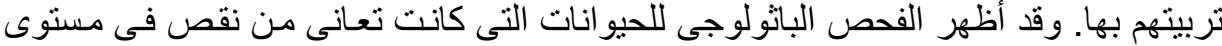

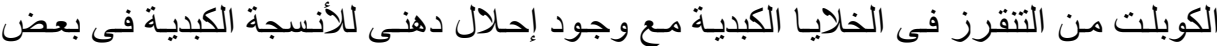

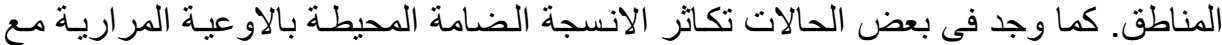

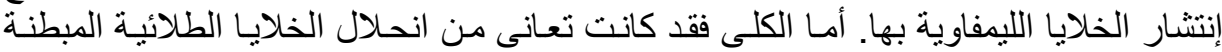
لأنابيب الكلى مع وجود جلطات متفرقة في الكبيبات. 


\section{SUMMARY}

Fifty animals, cattle and buffaloes (25 each) aged from 5-7 years old were selected randamly. They were raised at governmental project and slaughtered in Bani Adi and Elhawatka slaughter houses (Assiut, Egypt). Random samples of feed stuff and water (10 for each) were taken from the farm were the animals raised on. Haemogram showed that cattle and buffaloes suffering from cobalt deficiency had significantly decreased values of RBCs, $\mathrm{PCV}, \mathrm{Hb}, \mathrm{MCV}, \mathrm{MCH}, \mathrm{MCHC}$ and WBCs. According to serum biochemistry: cattle and buffaloes had lower levels of cobalt, significantly lower values of total proteins, albumin, and globulin. more over the activities of AST and ALT and the concentrations of blood urea nitrogen showing a marked increase in the animals suffered from lower cobalt levels. According to the histopathological findings: Livers of Codeficiency animals were exhibited varying degrees of vacuolar degeneration and necrotic changes with cytoplasmolysis and karyorhxis of the hepatic nucleus reached to its lyses. Diffuse fatty changes were also observed. The central veins were congested and surrounded with degenerated hepatocytes and increased number of kupffer cells some cases showed portal cirrhosis with lymphocytic infiltration. The kidneys showed sever degenerative changes in the renal tubules including cytoplasmolysis in the cytoplasm and lyses of the nucleus, congestion of the glomeruli were also observed. Therefore we should follow up cobalt levels in our farm animals to prevent its deficiency in our farms to prevent its deficiency in our farms in Assiut Governorate.

Key words: Cobalt, cattle, buffaloes, haemogram, histopathology.

\section{INTRODUCTION}

Cobalt (Co) is an essential trace element in ruminant diets for the production of vitamin B12 by the rumen microbes to meet the vitamin B12 requirements of both the ruminal bacteria and the host animal (McDowell, 1992). In higher animals, vitamin B12 is a cofactor for two enzymes, methylmalonyl-CoA mutase and methionine synthase.

The former catalyzes the interconversion of methylmalonyl-CoA to succinyl-CoA (Banerjee and Chowdhury, 1999), an important step in glucogenesis, while the latter acts to remethylate homocysteine, in the terminal step of methionine synthesis (Matthews, 1999). The NRC (2001) lists the dietary requirement of dairy cattle for Co as $0.11 \mathrm{mg} / \mathrm{kg}$ 
DM; relatively little is known about Co metabolism in cattle. Ruminants fed forages with Co concentrations $<0.08 \mathrm{mg} / \mathrm{kg}$ develop signs of Co/vitamin B12 deficiency (McDowell, 1997).

Necropsy of severely affected animals shows emaciation, often with total absence of body fat, liver fatty changes and occasional spleen haemosiderosis (Paterson and MacPherson, 1990; Kennedy et al., 1994) lambs are the most sensitive to Co deficiency, followed by mature sheep, calves, and mature cattle (McDowell, 2003; McDowell and Arthington, 2005).

Ruminants appear to be more sensitive to vitamin B12 deficiency than non-ruminants (NRC, 2001).

Elemental $\mathrm{Co}$ is absorbed through the intestinal tract and transported in blood to various tissues. The liver and the kidney contain the highest concentration of Co within tissues and are considered the main storage site (Underwood and Suttle, 1999).

Besides covering the requirements for vitamin B12 synthesis, Co may play a role in rumen fermentation by increasing fiber digestion from low quality forages (Zelenak et al., 1992; Stemme et al., 2008; Girard et al., 2009; Kumar et al., 2011).

In the present study, analysis of the animal feed, water, blood, blood serum, liver and kidney was conducted to establish the different Co levels in some selected individuals representing cattle and buffaloes and its effect in the different parameters in this study.

\section{MATERIALS and METHODS}

\section{Animals:}

Fifty animals, cattle and buffaloes (25 each) aged from 5-7 years old were selected randomly. They were chosen at governmental project and slaughtered in Bani Adi and Elhawatka slaughter houses (Assiut, Egypt).

\section{Blood sampling:}

Jugular blood samples were collected on EDTA for haematological evaluation and in plain vacutainer tubes for serum biochemistry. The blood was allowed to clot and centrifuged, then clear blood serum was separated and stored at $-20 \mathrm{C}^{\circ}$ until analysed.

Haematological parameters: Red blood cell counts (RBCs), packed cell volume (PCV), haemoglobin $(\mathrm{Hb})$ and white blood cell counts (WBCs) were determined according to Feldman et al. (2000). Red blood 
cell indices; mean corpuscular volume (MCV), mean corpuscular haemoglobin $(\mathrm{MCH})$ and mean corpuscular haemoglobin concentration (MCHC) were calculated.

Serum biochemistry: blood serum were analyzed spectrophotometrically for determination of total proteins (Henary et al., 1974), albumin (Doumas et al., 1971), and transferases (Aspartate amino transferase; AST and alanine amino transferase; ALT), and blood urea nitrogen (Patton and Crouch, 1977) using test kits supplied by Stanbio ITALY.

\section{Collection of liver and kidney samples:}

Liver and kidney samples were collected from the selected slaughtered cattle and buffaloes. The samples were transferred into clean sterile containers and immediately frozen at $-20{ }^{\circ} \mathrm{C}$ until analysed.

\section{3- Pathological studies:}

Tissue specimens from liver and kidneys were obtained immediately from the freshly slaughtered animals and fixed in 10\% neutral formalin solution dehydrated, cleared and embedded in paraffin blocks. Paraffin sections of $5 \mu$ thickness were prepared, stained by haematoxylin and eosin (H\&E) and osmium tetraoxide for demonstration of fat according to Bancroft et al. (1996). These stained sections examined microscopically for detection of histopathological alterations.

Food samples: Ten samples of concentrates and hay were taken and analysed using an atomic absorption spectrophotometer. Two grams of each sample was wet ashed in a Teflon beaker with cover using (1:3) $\mathrm{HNO}_{3} / \mathrm{HCLO}_{4}$ acid mixture. The residue after evaporation was dissolved in dilute $\mathrm{HCL}$ and completed to $50 \mathrm{ml}$ using bi-distilled water according to the method of Henary et al. (1974).

\section{Biochemical analysis:}

Blood serum concentrations of cobalt were measured by atomic absorption spectrophotometer (B3003, Perkin Elmer-AAS). Liver and kidney samples (one gram) were digested in a mixture of 2:1: 0.5 nitric acid (HNO, 65\%, Perchloric acid $\left(\mathrm{HCLO}_{4}, 60 \%\right)$ and sulphuric acid $\left(\mathrm{H}_{2} \mathrm{SO}_{4}, 97 \%\right)$. The samples were further diluted and aspirated into an atomic absorption spectrophotometer.

Statistical analysis: Recorded data were analyzed statistically using analysis of variance (ANOVA). The statistical differences between 
means were estimated by Duncons Multiple Range test. The computation was facilitated by statistical package SPSS (2000).

\section{RESULTS}

According to blood serum cobalt analysis, cattle $(0.23 \pm 0.02$ $\mu \mathrm{g} / \mathrm{ml})$ and buffaloes $(0.25 \pm 0.05 \mu \mathrm{g} / \mathrm{ml})$ (Table 1$)$ were considered Codeficient animals when comparing with the adequate levels of serum cobalt $(0.28 \pm 0.05 \mu \mathrm{g} / \mathrm{ml})$ recorded by Kincaid et al. (2003) and need more care for Co supplement.

In this study The cobalt level of the liver (Table 1) in cattle was $0.06 \pm 0.02 \mathrm{mg} / \mathrm{Kg}$ and in buffaloes was $0.08 \pm 0.03 \mathrm{mg} / \mathrm{Kg}$. while the kidney Co levels in cattle and buffaloes were $(0.03 \pm 0.01 \mathrm{mg} / \mathrm{Kg})$ and $(0.05 \pm 0.02 \mathrm{mg} / \mathrm{Kg})$ respectively.

Liver and kidney of large ruminants should be $>1.00 \mathrm{umol} / \mathrm{kg}$ $\mathrm{DM}$ in the normal conditions which consider an adequate amount of Cobalt as reported by Tiffany et al. (2003).

Our study revealed that the level of cobalt in forages and water (Table 1) introduced to the studied animals were 0.023 p.p.m and 0.01 p.p.m in cattle and 0.030 p.p.m and 0.01 p.p.m in buffaloes respectively. The levels of cobalt in forage and water considered decreased when it is $<0.10 \mathrm{mg} / \mathrm{kg}$ DM as recorded by Larry (2005)

Haemogram: cattle suffering from cobalt deficiency had significantly decreased $(\mathrm{P}<0.05)$ values (Table 2$)$, RBCs $(12.41 \pm 0.63$ $\mathrm{T} / 1), \operatorname{PCV}(31.88 \pm 0.63 \%), \mathrm{Hb}(9.16 \pm 0.25 \mathrm{~g} / \mathrm{dl}$ ), MCV (28.02 $\pm 2.65 \mathrm{fl})$, MCH $(7.63 \pm 0.30 \mathrm{pg}), \mathrm{MCHC}(31.83 \pm 2.10 \mathrm{~g} / \mathrm{dl}$ and WBCs $(7.49 \pm 0.10$ $\left.\left(10^{3} \mu 1 / 1\right)\right)$. Also buffaloes suffering from cobalt deficiency had significant decreased $(\mathrm{P}<0.05)$ values (Table 2$)$, RBCs $(11.03 \pm 0.30 \mathrm{~T} / \mathrm{l})$, $\mathrm{PCV}(32.3 \pm 1.36 \%), \mathrm{Hb}(8.6 \pm 0.48 \mathrm{~g} / \mathrm{dl}), \operatorname{MCV}(28.08 \pm 2.85 \mathrm{fl}), \mathrm{MCH}$ $(7.79 \pm 0.30 \mathrm{pg}), \mathrm{MCHC}(30.88 \pm 2.0 \mathrm{~g} / \mathrm{dl})$ and WBCs $\left(8.64 \pm 0.12\left(10^{3} \mu \mathrm{l} / \mathrm{l}\right)\right)$ than the normal values of RBCs $(13.43 \pm 0,34 \mathrm{~T} / 1), \operatorname{PCV}(40.45 \pm 0.62 \%)$, $\mathrm{Hb}(13.56 \pm 0.27 \mathrm{~g} / \mathrm{dl}), \mathrm{MCV}(29.05 \pm 2.65 \mathrm{fl}), \mathrm{MCH}(9.77 \pm 0.34 \mathrm{pg})$, MCHC $(33.42 \pm 0.29 \mathrm{~g} / \mathrm{dl})$ and WBCs $\left(11.81 \pm 0.15\left(10^{3} \mu 1 / 1\right)\right)$ reported by (Stangl et al., 1999).

Serum biochemistry: Cattle and buffaloes suffering from cobalt deficiency had significant lower $(\mathrm{P}<0.05)$ values (Table 3$)$ of total proteins $(4.01 \pm 0.06$ and $5.04 \pm 0.07 \mathrm{~g} / \mathrm{dl})$, albumin $(1.67 \pm 0.07$ and $1.78 \pm 0.04 \mathrm{~g} / \mathrm{dl})$, and globulin $(2.54 \pm 0.10$ and $2.86 \pm 0.17 \mathrm{~g} / \mathrm{dl})$ respectively, than the normal levels reported by Singh and Chhabara 
(1995) where the normal serum total proteins $(6.88 \pm 0.28 \mathrm{~g} / \mathrm{dl})$, albumin $(2.60 \pm 0.12 \mathrm{~g} / \mathrm{dl})$, and globulin $(4.26 \pm 0.24 \mathrm{~g} / \mathrm{dl})$.

The activities of serum enzymes (Table 3$)$ were $(244.23 \pm 11.8$ and327.34 $\pm 14.7 \mathrm{IU} / 1$ for AST in cattle and buffaloes respectively) and $(38.12 \pm 1.09$ and $40.0 \pm 1.34 \mathrm{IU} / \mathrm{l})$ for ALT in cattle and buffaloes respectively. The concentrations of blood urea nitrogen was $(15.11 \pm 1.07$ and $16.11 \pm 1.11 \mathrm{mg} / \mathrm{dl}$ ) in cattle and buffaloes respectively, showing a marked increase in the lower cobalt animals. Normal values of the activities of AST was (129.42 $\pm 9.11 \mathrm{IU} / \mathrm{l})$ and ALT was $(17.15 \pm 0.69)$ and the normal concentration of blood urea nitrogen was $(12.21 \pm 0.31)$ recorded by Singh and Chhabara (1995).

Table 1: Cobalt levels in Serum, liver, kidney, forage, water of cattle and buffaloes selected in this study:

\begin{tabular}{|c|c|c|}
\hline & Cattle & Buffaloes \\
\hline Serum $\mu \mathrm{g} / \mathrm{ml}$ & $0.23 \pm 0.02$ & $0.25 \pm 0.05$ \\
\hline Liver $\mathrm{mg} / \mathrm{Kg}$ & $0.06 \pm 0.02$ & $0.08 \pm 0.03$ \\
& & \\
\hline Kidney $\mathrm{mg} / \mathrm{Kg}$ & $0.03 \pm 0.01$ & $0.05 \pm 0.02$ \\
\hline Forage DM basis p.p.m & 0.023 & 0.030 \\
\hline Water p.p.m & 0.01 & 0.01 \\
\hline
\end{tabular}

Table 2: Haemogram of the selected cattle and buffaloes for this study:

\begin{tabular}{|l|c|c|}
\hline & Cattle & Buffaloes \\
\hline Red blood corpuscles(RBCs,T/l) & $12.41 \pm 0.63 \mathrm{~T} / 1$ & $11.03 \pm 0.30$ \\
\hline Packed cell volume (PCV \%) & $31.88 \pm 0.63$ & $32.3 \pm 1.36$ \\
\hline Haemoglobin (Hb-g/dl) & $9.16 \pm 0.25$ & $8.6 \pm 0.48$ \\
\hline $\begin{array}{l}\text { Mean corpuscular volume (MCV- } \\
\text { fl) }\end{array}$ & $28.05 \pm 2.65$ & $29.06 \pm 2.85$ \\
\hline $\begin{array}{l}\text { Mean corpuscular haemoglobin } \\
\text { (MCH-pg) }\end{array}$ & $7.63 \pm 0.30$ & $7.79 \pm 0.30$ \\
\hline $\begin{array}{l}\text { Mean corpuscular haemoglobin } \\
\text { concentration (MCHC-g/dl) }\end{array}$ & $31.83 \pm 2.10$ & $30.88 \pm 2.0$ \\
\hline $\begin{array}{l}\text { Total leukocytic count (WBCs } \\
\left.\times 10^{3} \mu 1 / 1\right)\end{array}$ & $7.49 \pm 0.10$ & $8.64 \pm 0.12$ \\
\hline
\end{tabular}

Mean \pm SE. $S E=$ standard Errors. $*=$ significant at $p=0.05$. 
Table 3: Serum biochemical parameters of the selected cattle and buffaloes for this study:

\begin{tabular}{|l|c|c|}
\hline & Cattle & Buffaloes \\
\hline Total proteins(g/dl) & $4.01 \pm 0.06$ & $5.04 \pm 0.07$ \\
\hline Albumin(g/dl) & $1.67 \pm 0.07$ & $1.78 \pm 0.04$ \\
\hline Globulin(g/dl) & $2.54 \pm 0.10$ & $2.86 \pm 0.17$ \\
\hline Albumin globulin ratio & $0.69 \pm 0.05$ & $0.72 \pm 0.07$ \\
\hline Aspartate amino transferase(AST-IU/l) & $244.23 \pm 11.8$ & $327.34 \pm 14.7$ \\
\hline Alanine amino transferase(ALT-IU/l) & $38.12 \pm 1.09$ & $40.0 \pm 1.34$ \\
\hline Urea nitrogen(mg/dl) & $15.11 \pm 1.07$ & $16.11 \pm 1.11$ \\
\hline
\end{tabular}

Mean \pm SE. $S E=$ standard Errors. ${ }^{*}=$ significant at $p=0.05$.

\section{Gross examination:}

The livers were characterized as uniformly pale, swollen and distinctly friable. It's cut surface is greasy and yellowish in color.

\section{Histopathological examination:}

Livers of Co-deficiency animals were exhibited varying degrees of vacuolar degeneration and necrotic changes with cytoplasmolysis and karyorhxis of the hepatic nucleus reached to its lyses (Fig 1,2). Diffuse fatty changes was also observed (Fig 3,4). The central veins were congested and surrounded with degenerated hepatocytes and increased number of kupffer cells (Fig 5) some cases showed portal cirrhosis with lymphocytic infiltration (Fig 6). The kidneys showed sever degenerative changes in the renal tubules including cytoplasmolysis in the cytoplasm and lyses of the nucleus congestion of the glomeruli was also observed (Fig 7). 


\section{LEGEND OF FIGURE}

Fig. 1: Liver of cobalt deficient animal showed vacuolar degeneration of the hepatocytes H\&E X40.

Fig. 2: Liver of cobalt deficient animal showed degenerative changes in the hepatocytes including kayorhexis of the nucleus and lyses of the cytoplasm hepatocytes H\&E X40.

Fig. 3: Liver of cobalt deficient animal showed fatty degeneration $H \& E$ X10.

Fig. 4: Liver of cobalt deficient animal showed fatty degeneration osmium tetraoxid stain X10.

Fig. 5: Liver of cobalt deficient animal showed congestion of the central vein which surrounded with degenerated hepatocytes and increased number of kupffer cells H\&E X40.

Fig. 6: Liver of cobalt deficient animal showed portal cirrhosis with infiltration of the portal area with lymphocytes H\&E X10.

Fig. 7: Kidney of cobalt deficient animal showed degenerative changes in both renal tubule and the glomeruli H\&E X40. 

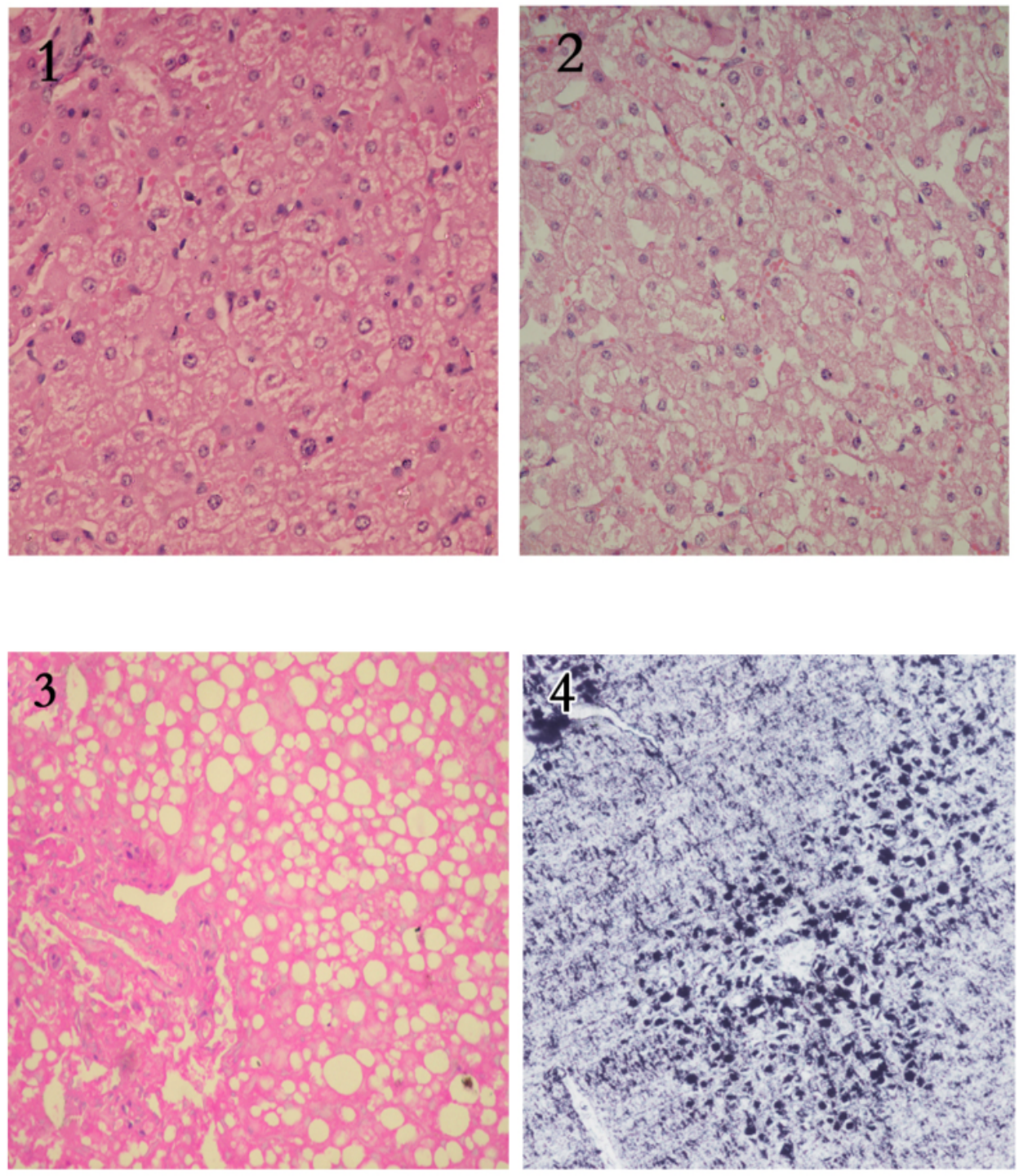
Assiut Vet. Med. J. Vol. 58 No. 132 January 2012
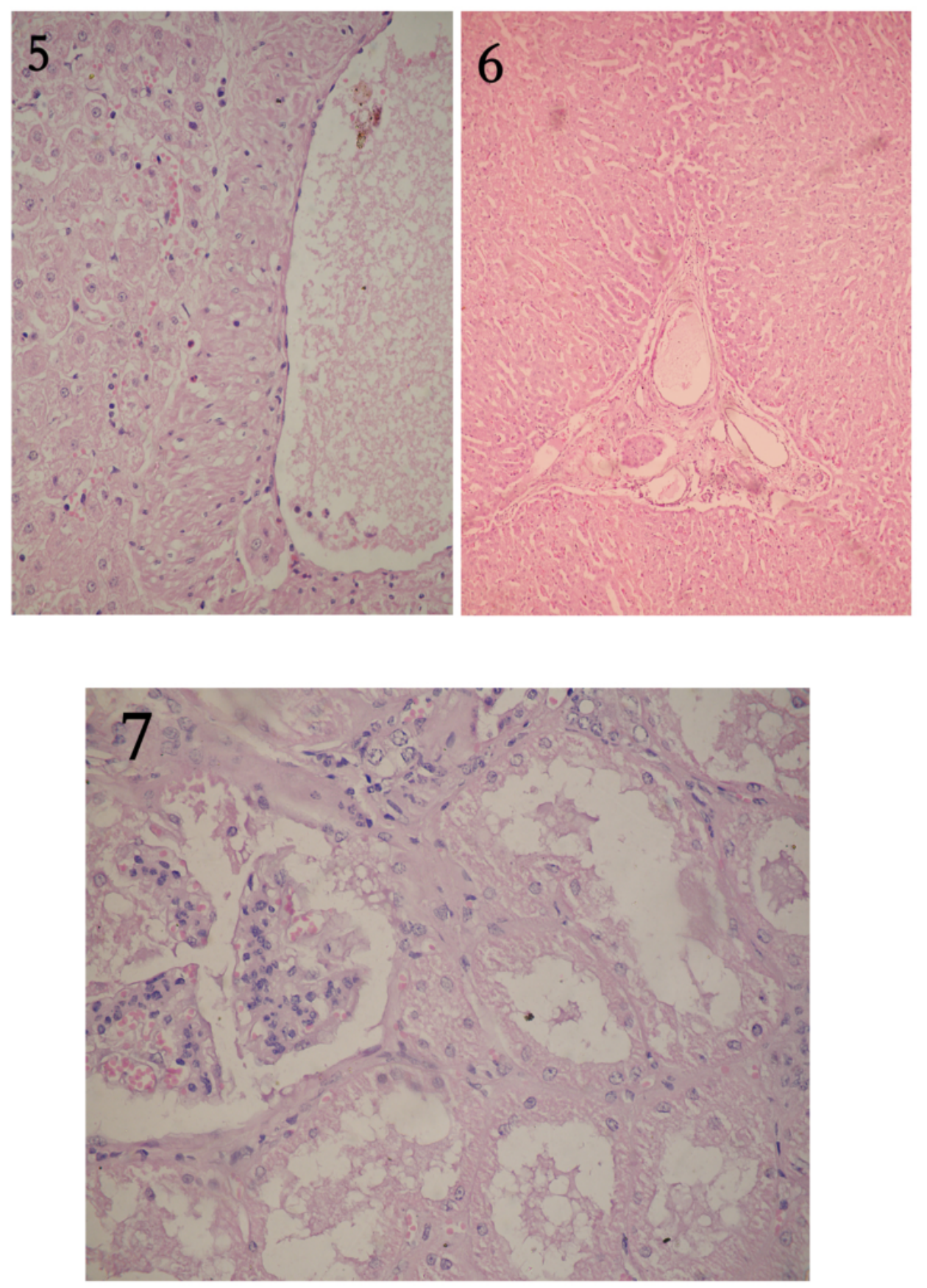


\section{DISCUSSION}

In general, cobalt deficiencies are frequent when high levels of mixed concentrates are fed. Cobalt deficiency in ruminants is of a major economic importance in several countries (Kennedy et al., 1997). More recent studies indicate the necessity to increase the amount of dietary Co for growing ruminants up to a level of $300-500 \mu \mathrm{g} / \mathrm{Kg}$ DM for optimum microbial activity, fermentation and vitB12 synthesis (Paragon, 1993 and Singh, Chhabara, 1995; Anonymous, 1996). Dietary Co requirements have been established at 0.1 to $0.3 \mathrm{ppm}$ (NRC, 2001). Signs of Co deficiency develop in ruminants fed diets that contain less than $70 \mu \mathrm{g} / \mathrm{Kg}$ DM (Marston, 1970; Lopez-Guisa and Satter, 1992 and Tiffany, 2003).

The present study showed that cobalt level in (blood serum, blood, liver, kidney, forages, and water) are considerably deficient for both cattle and buffaloes, in comparing with the different adequate cobalt levels recorded by Singh and Chhabara (1995); Stangl et al. (1999); Kincaid et al. (2003); Tiffany et al. (2003); Larry (2005).

Similar findings were reported by Khan (2003); Khan et al. (2006 and 2008).

In the current study, there was significant decrease in erythrogram parameters, (RBCs, $\mathrm{PCV}, \mathrm{Hb}, \mathrm{MCV}, \mathrm{MCH}$ and $\mathrm{MCHC}$ ) in Co deficient animals (cattle and buffaloes), in comparing with normal healthy values reported by other researches (Stangl et al., 2000; Khan et al., 2006 and 2008).

The Co deficient animals showed mild microcytic hypochromic anemia as manifested by reduced $\mathrm{MCV}$ and $\mathrm{MCHC}$.

The prominent feature of this study might be the decreased RBCs and $\mathrm{Hb}$, in these animals. These results give an indication about the importance of $\mathrm{Co}$ and its essential role in producing vit B12 and folate for the production of haem, Stangl et al. (1999).

The obtained results showed that the Co-deficient cattle and buffaloes exhibited a significant decrease in total serum proteins, albumin and globulin. Impairment of protein synthesis may be the principal reason for growth depression frequently observed in these animals. It may be also due to lower digestibility coefficients for dry matter (Singh and Chhabara, 1995; Stangl et al., 1999).

Also in this study Co, depleted cattle and buffaloes had elevated serum activities of AST and ALT., these findings are indicative of 
primary hepato cyte damage. Similar results were obtained by (Kennedy et al., 1997).

The histopathological findings as reported in this study support primary hepatocyte damage as the main lesion in liver of Co- deficiency animals. Although AST is not a liver specific enzyme, it has been reported to be elevated in cattle (Cebra et al., 1997) with hepatic lipidosis.

Significant elevation of blood urea nitrogen, as observed in the present study has also reported by (Stangl et al., 1999) in Co- deficient cattle and buffaloes. This result may be attributed to the disturbance in protein metabolism due to liver damage, which leads to accumulation of urea in blood (Kaneko, 1989).

Keeping in view this deficiency of cobalt in forages, water and intern in animals, best be prevented by direct oral intake of Co through mineral supplements (Khan et al., 2006 and 2008).

\section{REFERENCES}

Anonymous, (1996): Nutrient requirements of beef cattle (Seventh Ed.). National academy Press, Washington, D.C., 31: 1345-1354.

Bancroft, J.D.; Stevens, A. and Turner, D.R. (1996): Theory and practice of histological techniques 4th ed. Churchill Living Stone, New York Edinburgh. Madrid, Sanfrancisco, Tokyo.

Banerjee, R. and Chowdhury, S. (1999): Methylmalonyl-CoA Mutase. Pages 707-729 inChemistry and Biochemistry of B12. R. Banerjee, ed. John Wiley \& Sons, Inc. New York.

Cebra, C.K.; Garry, F.B.; Getzy, D.M. and Fettman, (1997): Hepatic lipidosis in anorectic, lactating Holstein cattle: a retrospective study of serum biochemical abnormalities, Journal of Veterinary Internal Medicine, 11: 321-237.

Doumas, B.; Watson, W. and Biggs, H. (1971): Albumin standards and measurement of serum albumin with bromocresol green. Clinica Chemica.Acta, 31: 87-96.

Feldman, B.; Joseph, J. and Jain, N. (2000): Schalms Veterinary Hematology. $5^{\text {th }}$ Ed., Lippincoot Williams and Wilkins Co. Philadelphia. 
Girard, CL.; Santschi, DE.; Stabler, SP. and Allen, RH. (2009): Appararent ruminal synthesis and intestinal disappearance of vitamin B12 and its analogs in dairy cows. J. Dairy Sci. 92: 4524-29.

Henary, R.; Cannon, D. and Winkleman, J. (1974): Clinical Chemistry Principles and Techniques. $2^{\text {nd }}$. ed. Harper and Roe, New York.

Kaneko, J.J. (1989): Clinical biochemistry of domestic animals. $4^{\text {th }}$ Ed. Academic Press, Inc., USA.

Kennedy, D.G.; Young, P.B.; Blanchflower, W.J.; Scott, J.M.; Weir, D.G.; Molloy, A.M. and Kennedy, S. (1994): Cobalt-vitamin B12 deficiency causes lipid accumulation, lipid peroxidation and decreased alpha-tocopherol concentrations in the liver of sheep. Int. J. Vitam. Nutr. Res. 64: 270-276.

Kennedy, S.; McConnell, S.; Anderson, H. and Blanchflower, W. (1997): Histopathological and ultrastructural alterations of white liver disease in sheep experimentally depleteted of cobalt. Veterinary Pathology, 34: 575-584.

Khan, Z.I. (2003): Effect of seasonal variation on the availability of macro-and micro, nutrients to animals (sheep and goats) through forage from soil. Ph.D Thesis Uni. Agric, Faisalabad, Pakistan. pp, 286.

Khan, Z.I.; Hussain, A.; Ashraf, M. and McDowell, L.R. (2006): Mineral Status of Soil and Forages in South Western Punjab, Pakistan. Asian-Aust. J. Anim. Sc., 19(8): 1139-1147.

Khan, Z.I.; Hussain, A.; Ashraf, M. and McDowell, L.R. (2008): A study on seasonal variability of trace elemental status of forages for ruminants in Pakistan. J. Plant Nutr.

Kincaid, R.L.; Lefebvre, L.E.; Cronrath, J.D. and Johnsont, A.B. (2003): effect of dietary cobalt supplementation on cobalt metabolism and performance of dairy cattle. J. Dairy Sci. 86: 1405-1414.

Kumar, S.; Pandey, A.; Abdul Razzaque, W.A. and Dwivedi, D.K. (2011): Importance of micro minerals in reproductive performance of livestock. Veterinary World, 5, 23.

Larry, L.B. (2005): Cobalt in ruminant nutrition. Salt and trace minerals, 37: 1-3. Am. J. Vet. Res. 47: 1776-1780.

Lopez-Guisa, J.M. and Satter, I.D. (1992): Effect of copper and cobalt addition on digestion and growth in heifers fed diets containing alfalfa silage on corn crop residues. J. Dairy Sci. 75: 247-256. 
Marston, H. (1970): The requirement of sheep for cobalt or vitamin B12. British journal of Nutrition, 24: 615-633.

Matthews, R.G. (1999): Cobalamin-dependent methionine synthase. Pages 681-706 in Chemistry and Biochemistry of B12. R. Banerjee, ed. John Wiley \& Sons, Inc. New York.

McDowell, L.R. (1992): Minerals in Animal and Human Nutrition. Academic Press, San Diego, California.

McDowell, L.R. (1997): Minerals for grazing ruminants. In: Tropical Regions. Extension Bull., Dept. Anim. Sci., Ctr. For Tropical Agric., Univ. of Florida Gainesville, FL. pp. 1-81.

McDowell, L.R. (2003): Minerals in animals and human nutrition. $2^{\text {nd }}$ ed. 144 p. Elsevier Science BV Amsterdam, Netherlands.

McDowell, L.R. and Arthington, J.D. (2005): Minerals for Grazing Ruminants in Tropical Regions, $5^{\text {th }}$ Ed. 86pp. University of Florida, Gainesville, Fl.

NRC, (2001): Nutrient requirements of dairy cattle. Seventh revised edition. National Academy Press, Washington D.C.

NRC, (2005): Mineral tolerance of animals.National Research Council of the National Academies, Second Revised Edition, National academic Press, Washington, D.C.

Paragon, B.M. (1993): Readjustment of the supply of cobalt in the ruminant: Critical approach. Recueil de Medicine Veternaire de Lecole dalfort, 169: 759-761.

Paterson, J.E. and MacPherson, A. (1990): A comparison of serum vitamin B12 and serum methylmalonic acid as diagnostic measures of cobalt status in cattle. Vet. Rec. 126: 329-332.

Patton, C. and Crouch, (1977): Calorimetric determination of urea. 49: 464-469.

Tiffany, M.E.; Spears, J.W. and Horton, J. (2003): Influence of dietary cobalt source and concentration on performance, vitamin b12 status and ruminal and plasma metabolites in growing and finishing steers. J. Anim. Sci., 81: 3151-3159.

Singh, K.K. and Chhabara, A. (1995): Effect of dietary cobalt on ruminal vitamin $\mathrm{B} 12$ synthesis and rumen metabolites. Journal of Nuclear Agricultural Biology, 24: 112-116. 
SPSS, (2000): Sample Power statistics, SPSS 11.5, Syntax reference Guide for SPSS Base. SPSS Inc., 233 South Wacker Drive, Chicago.

Stangl, G.I.; Schwarz, F.J. and Kirchgessner, M. (1999): Moderate long term cobalt deficiency affects liver Brain and erythrocyte lipids and lipoproteins of cattle. Nutrition Rescearchers, 19: 415-427.

Stemme, K.; Lebzien, P.; Flachowsky, G. and Scholz, H. (2008): The influence of an increased cobalt supply on ruminal parameters and microbial vitamin B12 synthesis in the rumen of dairy cows. Arch. Anim. Nutr., 62: 207-218.

Underwood, E.J. and Suttle, N.F. (1999): The Mineral Nutrition of Livestock, Third edition. CABI Publishing, Wallingford, United Kingdom.

Zeleñák, I.; Jalč, D.; Plachá, I.; Sviatko, P.; Vendrák, T.; Siroka, P. and Gyulai, F. (1992): The effect of copper and cobalt supplementation on the digestibility of fibrous feed in sheep. Vet. Med. (Prague), 37: 221-229. 